JKEP

Vol 3, No 1, Mei 2018

ISSN: 2354-6042 (Print)

ISSN : 2354-6050 (Online)

\title{
Pengaruh Intervensi Peer Group terhadap Kemampuan Koping Anak yang Menghadapi Abuse dan Neglect
}

\author{
Yupi Supartini, Ratna Ningsih \\ Jurusan Keperawatan Poltekkes Kemenkes Jakarta III \\ Email:yupi_riyanto@yahoo.com
}

\author{
Artikel history \\ Dikirim, Feb $17^{\text {th }}, 2018$ \\ Ditinjau, Maret $20^{\text {th }}, 2018$ \\ Diterima, April 26 ${ }^{\text {th }}, 2018$
}

\begin{abstract}
The purpose of this research to assess the influence of the peer group on coping abilities of teenagers who face abuse and neglect. Design studies used Quasi experiment. The population was children aged adolescents at high school, which was potentially facing abuse and neglect, in East Jakarta. The methode of sample selection was purposive sampling, determination of sample selection methdos have been due to a case of child abuse is a case that does not come to the surfacelan iceberg phenomenon, so that a relatively small number reported. Methodes of data collection using questionnaires that have been tested. The results showed no significant effect of group therapy activities against child coping skills in the face of abuse and neglect ( $p$ value=0,019). The implications of this study can give an idea of how carers can provide care to children potentially exposed to violence and neglect, especially in school and can be input for health services, especially in health centers School health programs in designing the program in anticipation of or prevention of abuse and neglect in children school environment. This program provide feedback on the guidance counselor to develop a counseling program using a model of peer group. For the future studies it is advisabled to involve the parents as respondents.

Keywords: Abuse and neglec; pilot stud; adolescen; pediatric nurse
\end{abstract}

\begin{abstract}
ABSTRAK
Tujuan dari penelitian ini untuk menilai pengaruh peer group terhadap kemampuan koping remaja yang menghadapi pelecehan dan pengabaian. Desain studi menggunakan eksperimen semu. Populasinya adalah anak-anak berusia remaja di sekolah menengah, yang berpotensi menghadapi pelecehan dan penelantaran, di Jakarta Timur. Metode pemilihan sampel dilakukan dengan purposive sampling, penentuan metode pemilihan sampel karena kasus pelecehan anak adalah kasus yang tidak muncul ke permukaan/fenomena gunung es, sehingga relatif kecil nomor yang dilaporkan. Metode pengumpulan data menggunakan kuesioner yang telah diuji. Hasil penelitian menunjukkan tidak ada pengaruh yang signifikan dari kegiatan terapi
\end{abstract}


kelompok terhadap keterampilan koping anak dalam menghadapi pelecehan dan penelantaran (nilai $\mathrm{p}=0,019$ ). Implikasi dari penelitian ini dapat memberikan gambaran tentang bagaimana pengasuh dapat memberikan perawatan kepada anakanak yang berpotensi terkena kekerasan dan penelantaran, terutama di sekolah dan dapat menjadi masukan untuk layanan kesehatan, terutama di pusat kesehatan Program Usaha Kesehatan Sekolah dalam merancang program untuk mengantisipasi atau mencegah pelecehan dan penelantaran di lingkungan sekolah anak-anak. Program ini memberikan umpan balik pada konselor bimbingan untuk mengembangkan program konseling menggunakan model peer group. Untuk penelitian selanjutnya disarankan untuk melibatkan orang tua sebagai responden.

Kata Kunci: Pelecehan dan penelantaran; studi percontohan; remaja; perawat anak

\section{PENDAHULUAN}

Permasalahan anak di Indonesia sampai saat ini masih kompleks. Terdapat 17.7 juta anak yang berada dalam keadaan sulit (Kompas, 23 Februari 2010). Hal ini menunjukkan adanya potensi kejadian abuse dan neglect yang cukup tinggi, anak yang menjadi objek eksploitasi orang tua, anak dengan malnutrisi, anak2 yang tinggal dalam tahanan/penjara, diluar anakyang hidup dengan HIV/Aids dan mereka yang mendapat diskriminasi oleh berbagai alasan seperti etnis dan agama. Beberapa upaya telah banyak dilakukan untuk mengatasi masalah tersebut diatas, dengan komitmen dari semua professional kesehatan dan pemerintah.Walaupun demikian, permasalahan belum terpecahkan secara komprehensif.

Pada kenyataannya, tidak cukup komitmen yang diberikan tanpa tindakan nyata untuk mengimplementasikan semua aturan yang bertujuan untuk melindungi hak hak anak.Beberapa regulasi yang telah dipublikasikan oleh pemerintah Indonesia ke masyarakat sebagai satu komitmen untuk melaksanakan Sistem Perlindungan Anak Indonesia seperti dengan terbitnya Keputusan Pesiden RI no 36/1990 sebagai suatu inisiasi upaya Perlindungan Anak di Indonesia; Undang Undang No 3/1997 yang meregulasi dan memberikan perhatian pada anak yang dicurigai melakukan tindakan kriminal. Dokumen terakhir dari regulasi pemerintah ini adalah Undang Undang No 23 tahun 2002 tentang Perlindungan Anak yang memandang secara komprehensif upaya perlindungan anak di Indonesia. Untuk melaksanakan Perlindungan anak, pemerintah telah menugaskan kepada Komisi Perlindungan Anak sebagai 
Institusi Independen yang dapat memberikan advokasi dan mendorong kepada pemerintah tentang setiap hal yang berhubungan dengan isu tersebut. Akhirnya, pemerintah telah mengintegrasikan Perlindungan anak pada Kementerian dan Pemberdayaan wanita untuk mengatasi isu dan semua permasalahan perlindungan anak dalam perspektif upaya pemerintah.

Semua upaya Perlindungan anak tersebut diatas menunjukkan adanya Sistem Perlindungan Anak telah dibangun, akan tetapi kasus-kasus kekerasan dan penelantaran pada anak selalu muncul di beberapa tempat di Indonesia. "Fenomena Gunung Es" (The Ice Berg Phenomeno) muncul sebagai symbol dari kasus abuse dan neclect pada anak. Apakah ada kekurangan dalam melaksanakan sistem Perlindungan Anak atau tidak jelasnya pola atau model yang dapat digunakan secara efektif. Tim multidisiplin yang telah dirancang sebagai satu bagian dari Sistem Perlindungan Anak Indonesia, dalam pelaksanaannya belum optimal.

Masyarakat sebagai bagian dari tim penanggulangan Kekerasan dan Penelantaran pada anak, mempunyai peran penting untuk memutus mata rantai Kekerasan dan Penelantaran pada Anak, khususnya pada keluarga dimana anak tinggal bersama mereka sepanjang waktu.Walaupun demikian, harus diwaspadai, bahwa kasus kekerasan pada anak $60 \%$ berasal dari keluarga atau "Domestic Violence " (UNICEF, 2006). Walaupun Indonesia telah melaksanakan upaya perlindungan anak, lebih berfokus pada manajemen kedaruratan saja. Tidak ada tempat bagi keluarga dan juga anak untuk dapat berbagi pengalaman, belajar satu dengan yang lain untuk mengatasi permasalahan, supaya tumbuh kembang anak dapat terus berlangsung.

Berkaitan dengan potensi terjadinya abuse dan neglect pada anak di lingkungan sekolah, data dari Komisi Perlindungan Anak Indonesia (KPAI) pada 2014, kekerasan pelajar mulai umur 9-20 tahun yang dilaporkan ke kepolisian meningkat $20 \%$ pada tahun 2013. Kemudian, hasil survei oleh KPAI di sembilan provinsi, yaitu Sumatera Barat, Lampung, Jambi, Banten, Jawa Tengah, DIY, Jawa Barat, Jawa Timur, dan Kalimantan Timur, dengan total responden 1.026 siswa, menyebutkan masih tingginya tindak kekerasan pada siswa. Kekerasan dalam pendidikan juga 
dilaporkan dilakukan guru, seperti kasus dugaan pelecehan seksual di SMAN 22 Jakarta, SD negeri di Depok, atau dugaan kekerasan fisik yangdilakukan guru di salah satu SD negeri di Tanjung Priok. Mengapa kekerasan terhadap siswa masih terus terjadi di sekolah yang mestinya menjadi rumah kedua bagi mereka? Bagaimana sebaiknya para pemangku kepentingan dapat memutus "mata rantai'tindakan "abuse dan neglect" pada siswa?. Penelitian ini bertujuan untuk mengetahui pengaruh intervensi kelompok sebaya terhadap koping anak yang mengalami abuse dan neglect.

\section{METODE}

Penelitian kuantitatif ini menggunakan desain quasi experiment pre-pos test without control group dengan intervensi terapi Peer group. Penelitian ini membandingkan kemampuan koping anak sebelum dan sesudah diberikan intervensi terapi Peer group. Responden merupakan siswa Sekolah Menengah Atas. Jumlah responden yang menjadi sample adalah 30 orang.

\section{HASIL DAN PEMBAHASAN}

Analisa penelitian berdasarkan prosedur analisa univariat dan bivariat. Pada analisa univariat penelitian ini akan dijelaskan karakteristik responden dan gambaran kejadian abuse dan neglect responden secara deskriptif. Gambaran terlihat pada tabel 1 dan 2:

Tabel 1.Distribusi Karakteristik Anak $(n=30)$

\begin{tabular}{llcc}
\hline \multirow{2}{*}{ Variabel } & Kategori & \multicolumn{2}{c}{ Jumlah } \\
\cline { 3 - 4 } Jenis kelamin & Laki-laki & 18 & 60 \\
& Perempuan & 12 & 40 \\
\hline \multirow{2}{*}{ Urutan anak di keluarga } & Anak ke-1 & 17 & 56,7 \\
& Anak ke-2 & 5 & 16,7 \\
& Anak ke-3 & 5 & 16,7 \\
\multirow{2}{*}{ Anak membantu } & Anak ke-4 & 3 & 10 \\
mencari nafkah & Ya & 2 & 6,7 \\
& Tidak & 28 & 93,3 \\
\hline
\end{tabular}

Tabel 1 menunjukkan bahwa jenis kelamin anak mayoritas laki-laki
$(60 \%)$, urutan anak dalam keluarga mayoritas merupakan anak pertama 
dan hanya $6,7 \%$ anak yang membantu orang tuanya mencari nafkah. Dari tabel 2 memperlihatkan bahwa mayoritas pendidikan ayah adalah Perguruan Tinggi (70\%) dan bekerja $(93,4 \%)$. Demikian juga pendidikan ibu mayoritas Perguruan Tinggi (70\%), dan lebih dari separuhnya tidak bekerja (60\%). Penghasilan keluarga mayoritas $\geq$ UMR (90\%), mayoritas ayah/ibu tidak temperamental $(67,7 \%)$ dan mayoritas tidak bercerai $(93,3 \%)$.
Sebagian besar responden berusia ratarata 15,97 tahun berjenis kelamin pria, anak ke-1, tidak membantu orangtua mencari nafkah, dengan ayah berusia rata-rata 51,07 tahun, ayah bekerja sebagai karyawan swasta dengan latar belakang pendidikan ayah perguruan tinggi, dan ibu berusia rata-rata 46,43 tahun, ibu berpendidikan perguruan tinggi dan tidak bekerja, dengan penghasilan keluarga perbulan $\geq U M R$.

Tabel 2. Distribusi Karakteristik Lingkungan $(n=30)$

\begin{tabular}{|c|c|c|c|}
\hline \multirow[b]{2}{*}{ Variabel } & \multirow[b]{2}{*}{ Kategori } & \multicolumn{2}{|c|}{ Jumlah } \\
\hline & & $\mathrm{n}$ & $\%$ \\
\hline \multirow[t]{3}{*}{ Pendidikan Ayah } & SMP & 1 & 3,3 \\
\hline & SMA & 8 & 2,7 \\
\hline & PT & 21 & 70 \\
\hline \multirow[t]{2}{*}{ Pekerjaan Ayah } & Bekerja & 28 & 93,4 \\
\hline & Tdk Bekerja & 2 & 6,6 \\
\hline \multirow[t]{2}{*}{ Pendidikan Ibu } & SMA & 9 & 30 \\
\hline & PT & 21 & 70 \\
\hline \multirow[t]{2}{*}{ Pekerjaan Ibu } & Bekerja & 12 & 40 \\
\hline & Tdk Bekerja & 18 & 60 \\
\hline Pengasilan keluarga per & $<\mathrm{UMR}$ & 3 & 10 \\
\hline bulan & $\geq \mathrm{UMR}$ & 27 & 90 \\
\hline \multirow[t]{2}{*}{ Ayah/ibu temperamental } & $\mathrm{Ya}$ & 7 & 23,3 \\
\hline & Tidak & 23 & 67,7 \\
\hline \multirow[t]{2}{*}{ Orangtua Bercerai } & $\mathrm{Ya}$ & 2 & 6,7 \\
\hline & Tidak & 28 & 93,3 \\
\hline
\end{tabular}

Gelles Richard (1982) menyatakan bahwa penyebab terjadinya kekerasan pada anak antara lain; pengaruh keluarga; keadaan sosial ekonomi 
keluarga; atau aspek pewarisan kekerasan antar generasi (intergenerational transmission of violance) dimana anak belajar melakukan tindakan kekerasan pada orang tuanya yang melakukan kekerasan pada anak. Pendapat lain yaitu Goleman (2003) menyatakan bahwa kehidupan keluarga merupakan sekolah pertama kita mempelajari emosi, dalam lingkungan yang akrab ini kita belajar bagaimana merasakan perasaan kita sendiri dan bagaimana orang lain menanggapi perasaan kita, bagaimana berpikir tentang perasaan ini dan pilihan-pilihan apa yang kita miliki untuk bereaksi. Berdasarkan data KPAI (2012), menunjukkan bahwa anak usia 13 - 18 tahun paling banyak mengalami kekerasan.

Hasil skor kemampuan koping anak yang mengalami abuse dan neglect terlihat pada tabel 3. Sebelum intervensi mean: 56,3, median : 57, skor minimum: 42 dan maksimum: 65, sedangkan skor kemampuan koping setelah intervensi mean : 58,7, median : 58,5, skor minimum: 46 dan skor maksimum: 71 dengan selisih peningkatan skor koping mean : 2,4 dan selisih skor median: 1,5 .

Tabel 3. Distribusi skor kemampuan koping anak yang mengalami abuse dan neglect sebelum dan sesudah intervensi peer group $(n=30)$

\begin{tabular}{ccccc}
\hline Variabel & Mean & Median & Minimum & Maksimum \\
\hline Pre Test & 56,3 & 57 & 42 & 65 \\
Post Test & 58,7 & 58,5 & 46 & 71 \\
Selisih & 2,4 & 1,5 & &
\end{tabular}

Tabel di atas menunjukkan bahwa kemampuan koping anak dalam mengatasi masalah abuse dan neglect mengalami peningkatan setelah dilakukan intervensi berupa edukasi tentang konsep kekerasan dan penelantaran pada anak serta kopingnya baik koping positif maupun koping negatif. Selanjutnya dilakukan diskusi kelompok untuk sharing pemahaman tentang kekerasan dan penelantaran pada anak serta koping yang diharapkan (positif). Selain itu dilakukan sharing pengalaman anak dalam menghadap kekerasan dan penelantaran serta cara mengatasinya oleh masing-masing anak dalam kelompok. Hal ini sejalan dengan penelitian Riyanti (1996) yang menyatakan bahwa kelompok sebaya (peer group) adalah salah satu ciri yang dibentuk dalam perilaku sosial 
dimana perilaku kelompok tersebut akan mempengaruhi perilaku serta nilai-nilai individu-individu yang menjadi anggotanya sehingga individu tersebut akan membentuk pola perilaku dan nilai-nilai yang baru yang pada gilirannya dapat menggantikan nilainilai serta pola perilaku yang dipelajari di rumah. Hal ini juga relevan dengan hasil penelitian Rohmah (2013) yang menyatakan bahwa bahwa peer group dapat berperan penting untuk mengajarkan kebudayaan, megajarkan mobilitas sosial, membantu peranan sosial yang baru, sumber informasi, belajar saling bertukar perasaan dan masalah, mengajarkan moral orang dewasa, individu dapat mencapai kebebasan berpendapat, bertindak tau menemukan identitas diri, dan belajar mengontrol tingkah laku sosial.

Pengaruh intervensi kelompok sebaya (Peer group) terhadap kemampuan koping remaja yang mengalami abuse dan neglect dilakukan dengan menggunakan uji $\mathrm{T}$ berpasangan (paired $t$ test) pada tingkat kemaknaan $5 \%$ Hasil analisis tersebut digambarkan pada tabel 4 .

Tabel 4. Analisis kemampuan koping anak yang mengalami abuse dan neglect sebelum dan sesudah intervensi peer group

\begin{tabular}{lccccc}
\hline Variabel & Mean & SD & t & df & p-value \\
\hline $\begin{array}{l}\text { Kemampuan } \\
\text { koping anak }\end{array}$ & 2,40 & 5,52 & 2,379 & 29 & 0,024 \\
\hline
\end{tabular}

peneliti melakukan pengujian kovariat

Hasil analisis menunjukkan bahwa terdapat peningkatan skor kemampuan koping pada responden yang mendapat perlakuan dengan besarnya peningkatan skor 2,4 pada nilai $\mathrm{t}=$ 2,379 dan p-value 0,024. Sehingga dapat disimpulkan bahwa terdapat pengaruh signifikan intervensi kelompok sebaya pada p-value 0,001 terhadap peningkatan skor ketrampilan koping responden. Setelah diketahui peningkatan pengaruh intervensi, untuk mengetahui faktor-faktor yang ikut berpengaruh dalam peningkatan skor keterampilan remaja dengan abuse dan neglect dengan menggunakan Uji Ancova (Tabel 5).

Terdapat 5 variabel yang menjadi faktor kovariat pada peningkatan skor ketrampilan koping pada responden yaitu jenis kelamin siswa, pendidikan ibu, penghasilan keluarga perbulan, ayah/ibu temperamental dan orangtua 
bercerai pada p-value: 0,019 . Hal ini membuktikan bahwa karakteristik anak mempengaruhi pola koping mereka dalam menghadapi kekerasan dan penelantaran setelah mereka berinteraksi dalam kelompok sebayanya, melalui diskusi dan sharing pengalaman. Apa yang dialami oleh anggota kelompok sebaya mempengaruhi kemampuan anak dalam mengatasi masalahnya.

Tabel 5 Analisis pengaruh karakteristik anak dan lingkungan terhadap kemampuan koping anak yang mengalami abuse dan neglect menggunakan Uji Ancova

\begin{tabular}{lcccc}
\hline Variabel & $\begin{array}{c}\text { Mean } \\
\text { Square }\end{array}$ & df & F & p-value \\
& 128,921 & 1 & 13,805 & 0,005 \\
Jenis Kelamin & 55,106 & 3 & 5,901 & 0,038 \\
$\begin{array}{l}\text { Pendidikan Ibu } \\
\text { Penghasilan keluarga }\end{array}$ & 62,819 & 1 & 6,727 & 0,011 \\
perbulan & & & & \\
Ayah/ibu & 74,607 & 1 & 7,989 & 0,020 \\
temperamental & 241,671 & 1 & 25,879 & 0,001 \\
$\begin{array}{l}\text { Orangtua bercerai } \\
\text { Model }\end{array}$ & 37,313 & 20 & 3,996 & 0,019 \\
\hline
\end{tabular}

Kuatnya pengaruh teman sebaya tidak terlepas dari adanya ikatan yang terjalin kuat dalam kelompok teman sebayanya tersebut (peer group), sedemikian kuatnya sehingga mengarah ke fanatisme, sehingga tiaptiap anggota kelompok menyadari bahwa mereka adalah satu kesatuan yang terkait dan saling mendukung, dimana kelompok teman sebaya (peer group) merupakan kelompok yang terdiri dari teman seusianya dan mereka dapat mengasosiasikan dirinya (Chaplin, 2001). Menurut Santrock (2003), pada banyak remaja, bagaimana mereka dipandang oleh teman sebaya merupakan aspek yang terpenting dalam kehidupan mereka, bahkan remaja akan melakukan apapun agar dapat dimasukkan sebagai anggota.

Terapi kelompok merupakan suatu psikoterapi yang dilakukan sekelompok pasien bersama-sama dengan jalan berdiskusi satu sama lain yang dipimpin atau diarahkan oleh seorang therapist atau petugas kesehatan jiwa yang telah terlatih. Terapi kelompok dilakukan secara kelompok untuk memberikan stimulasi bagi pasien dengan gangguan interpersonal (Yosep, 2008). Proses terapi aktivitas kelompok pada 
dasarnya lebih kompleks dari pada terapi individual, oleh karena itu untuk memimpinnya memerlukan pengalaman dalam psikoterapi individual. Dalam kelompok, terapis akan kehilangan otoritasnya dan menyerahkan kepada kelompok.

Skinner dan Zimmer-Gembeck (dalam Hernandez, 2006) mengemukakan bahwa strategi koping yang paling efektif adalah yang paling sesuai dengan jenis stres dan situasi yang dihadapi. Strategi yang dipilih individu untuk mengatasi distress yang dialami, memiliki efek jangka panjang dan berpengaruh pada bagaimana mereka mengatasi situasi di masa depan. Koping yang adaptif dapat membantu individu mendapatkan pemahaman dan mencegah situasi penuh stres seiring pertambahan usianya, dan sejalan dengan meningkatnya ketabahan di masa depan.

Hasil penelitian menunjukkan bahwa karakteristik remaja dan lingkungan yang berpengaruh terhadap kemampuan koping anak yang mengalami abuse dan neglect adalah jenis kelamin siswa, pendidikan ibu, penghasilan keluarga, ayah/ibu temperamental dan orangtua bercerai.
Tipe-tipe keluarga tertentu memiliki risiko yang meningkat untuk melakukan tindakan kekerasan dan pengabaian kepada anak. Misalnya, orang tua tunggal lebih memungkinkan melakukan tindakan kekerasan terhadap anak dibandingkan dengan orang tua utuh. Selain itu, keluarga dimana baik suami atau istri

Penelitian ini mempunyai keterbatasan yaitu tidak melibatkan orang tua sebagai responden.

\section{SIMPULAN}

Penelitian ini membuktikan bahwa jenis kelamin siswa, pendidikan ibu, penghasilan keluarga perbulan, ayah/ibu temperamental dan orangtua yang bercerai dapat menyebabkan terjadinya kekerasan pada anak, serta membentuk pola koping anak.Terdapat perbedaan kemampuan koping anak dalam menghadapi abuse dan neglect pada sebelum dan sesudah terapi peer group. Intervensi yang dilakukan berupa pemberian edukasi tentang konsep kekerasan dan penelantaran pada anak serta koping yang positif yang harus dimiliki oleh anak terbukti dapat meningkatkan kemampuan dalam memahami bagaimana menyelesaikan masalah kekerasan dan 
penelantaran yang dialami.

Keberadaan peer group terbukti berperan penting bagi anak remaja terutama untuk memberikan penguatan dalam mengambil keputusan untuk merespon masalah kekerasan dan penelantaran yang dialami anak.

\section{DAFTAR RUJUKAN}

Baron, R. A., \& Byrne, Donn. 2003. Psikologi Sosial Edisi 10 Jilid 5. Jakarta : Erlangga.

Baron, R. A. (2003). Psikologi Sosial Jilid 2 Edisi Sepuluh.Jakarta : Erlangga

Desmita (2005). Psikologi Perkembangan.Bandung : PT. Remaja Rosdakarya.

Etheses.uinmalang.ac.id/2288/5/06410053. Diakses Desember 2015

Fisher, A.A., Laing, J.E., Stockel, J.E., \& Townsend, J.W. 1999. Handbook for Family Planning Operations Research Design. $2^{\text {nd }}$ ed. New York : Population Council.

Hockenberry, J.M.,\& Wilson, D. 2007. Wong's nursing care of infants and children". 8th edition. Canada: Mosby Company.

Juliaan, F. 2008. Penelitian Operasional (OR) : Pengertian dan Metode. Puslitbang KB dan Kesehatan Reproduksi. Jurnal Ilmiah KB \& Kesehatan Reproduksi, Thn II No.2.
Kementerian Kesehatan Indonesia, 2004 Penatalaksanaan Child Abuse dan Neglect pada Anak bagi tenaga professional kesehatan.Kerjasama UNICEF dengan Ikatan Dokter Indonesia. Kemenkes RI.

Lemeshow, S., Holmer, D.W., Klar, J., \& Lwanga, S.K. 2002. Besar Sampel dalam Penelitian Kesehatan. (Pramono, D., \& Kusnanto, H., Penerjemah). Yogyakarta : Gadjah Mada University Press.

Polit, D.F., Beck, C.T., \& Hungler, B.P. 2001. Essentials of nursing research: Methods, appraisal and utilization. Philadelphia: Lippincott Williams \& Wilkins.

Santosa, S., 1999. Dinamika Kelompok. Jakarta: Bumi Aksara.

Sear, O. D., Freedman, J, L. \& Peplau, L. A. 1985. Psikologi Sosial Edisi Kelima Jilid I. Jakarta : Erlangga.

Undang Undang No. 23 tahun 2002. Perlindungan Anak

Wood, G.L., \& Haber, J. 2006. Nursing Research : Methods and Critical Appraisal for Evidence-Based Practice. St. Louis : Mosby-Elsevier. 